\title{
触 New Disease Reports \\ Dieback and mortality of Juniperus communis in Britain associated with Phytophthora austrocedrae
}

\author{
S. Green*, S.J. Hendry, G.A. MacAskill, B.E. Laue and H. Steele \\ Forest Research, Northern Research Station, Roslin, Midlothian, EH25 9SY, Scotland \\ *E-mail: sarah.green@ forestry.gsi.gov.uk
}

Received: 11 Apr 2012. Published: 31 Jul 2012. Keywords: Juniper, decline

In late 2010 reports were received of serious decline of native juniper (Juniperus communis) at the Upper Teesdale National Nature Reserve in northern England comprising more than 200 ha of juniper. Dead and dying juniper trees were scattered throughout an area of approximately 14 ha, mainly concentrated on wet, flat ground but also extending outwards across drier slopes. Affected trees had foliage reddening and browning over all or most of the crown (Figs. 1, 2). Examination of ten trees showing these symptoms revealed orange-brown lesions in the phloem at the stem collar and upper roots (Fig. 3). Scattered dieback of shoots or individual branches (Fig. 4a) was also observed, and three trees examined with these symptoms had discrete girdling orange-brown phloem lesions with no apparent connection to the base of the tree (Fig. 4b). Phloem samples from lesion margins were plated on to SMA + MRP Phytophthora selective medium (Brasier et al., 2005) and incubated at room temperature $\left(15-24^{\circ} \mathrm{C}\right)$ in the dark. After transfer to V8 agar, colonies were very slow growing $\left(<0.5 \mathrm{~mm}\right.$ per day at $\left.17^{\circ} \mathrm{C}\right)$, forming dense, white mycelia (Fig. 5a) with coralloid hyphae (Fig. 5b); amphigynous antheridia measuring 10.8-19.9 $\mu \mathrm{m}$ in diameter (mean 13.2-16.2 $\mu \mathrm{m}$ ); and globose oogonia with smooth hyaline to brown walls ranging in diameter between 23.5-41.2 $\mu \mathrm{m}$ (mean $34.4 \mu \mathrm{m}$ ). Semi- and non-papillate sporangia measuring 35.3-58.8 $\times 23.5-35.3 \mu \mathrm{m}$ were also observed on V8 agar. Based on the above morphological characteristics and sequencing of the ITS and coxII regions (GenBank Accession Nos. JQ346527 and JQ346528), the isolates were identified as Phytophthora austrocedrae Gresl. \& E.M. Hansen, associated with mortality of Austrocedrus chilensis in Argentina (Greslebin et al., 2007; Greslebin \& Hansen, 2010). Direct PCR and sequencing of diseased phloem from basal and branch lesions on juniper trees from which no Phytophthora was obtained yielded the same result.

Pathogenicity of the isolate was tested using the method of Greslebin \& Hansen (2010) in which the stem bases of six healthy, 30-40 cm high, potted junipers were inoculated with $6 \mathrm{~mm}$ diameter mycelial plugs from the margin of a five-week-old $P$. austrocedrae culture growing on V8 agar. The plants were incubated in a greenhouse at $17^{\circ} \mathrm{C}$ with natural lighting. Four weeks after inoculation, five of the juniper plants exhibited orange-brown phloem lesions of mean length $49 \pm 8 \mathrm{~mm}$ extending both up the main stem and down into the root system. P. austrocedrae was successfully re-isolated on to SMA + MRP medium from lesion margins, thereby satisfying Koch's postulates. Control plants inoculated with sterile agar plugs remained healthy. This is the first finding of $P$. austrocedrae infecting a Juniperus species worldwide. Although $P$. austrocedrae is not currently a statutory listed organism within the European Union, biosecurity measures are being applied at the infested site to contain the pathogen. In February $2012 P$. austrocedrae was confirmed infecting mature upland juniper at a second site in Britain, located in Perthshire, Scotland. Other juniper sites in Britain with similar decline symptoms are now under investigation.

\section{Acknowledgements}

We thank Martin Furness and Chris McCarty of Natural England for assistance with field sampling, Dr Alexandra Schlenzig of Science and Advice for Scottish Agriculture (SASA) for assistance with pathogenicity testing.

\section{References}

Brasier CM, Beales PA, Kirk SA, Denman S, Rose J, 2005. Phytophthora kernoviae sp. nov., an invasive pathogen causing bleeding stem lesions on forest trees and foliar necrosis of ornamentals in Britain. Mycological Research 109, 853-859. [http://dx.doi.org/10.1017/S0953756205003357]

Greslebin AG, Hansen EM, 2010. Pathogenicity of Phytophthora austrocedrae on Austrocedrus chilensis and its relation with mal del ciprés in Patagonia. Plant Pathology 59, 604-612. [http://dx.doi.org/10.1111/j.1365-3059.2010.02258.x]

Greslebin AG, Hansen EM, Sutton W, 2007. Phytophthora austrocedrae sp. nov., a new species associated with Austrocedrus chilensis mortality in Patagonia (Argentina). Mycological Research, 308-316. [http://dx.doi.org/dx.doi.org/10.1016/j.mycres.2007.01.008]

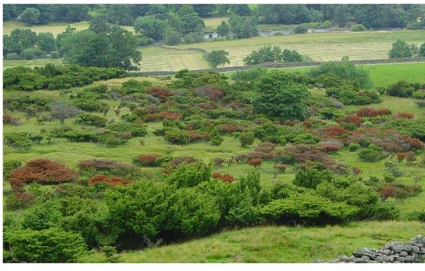

Figure 1

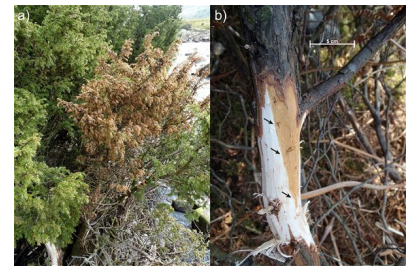

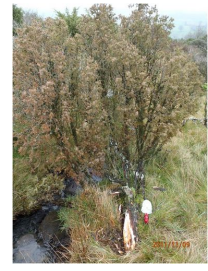

Figure 2

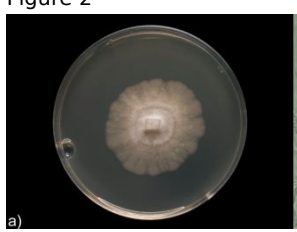

Figure 5

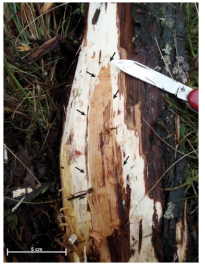

Figure 3

Figure

To cite this report: Green S, Hendry SJ, MacAskill GA, Laue BE, Steele H, 2012. Dieback and mortality of Juniperus communis in Britain associated with Phytophthora austrocedrae. New Disease Reports 26, 2. [http://dx.doi.org/10.5197/j.2044-0588.2012.026.002]

(c) 2012 The Authors

This report was published on-line at www.ndrs.org.uk where high quality versions of the figures can be found. 